\title{
REVIEW
}

Open Access

\section{Outcomes of neonatal hypothermia among very low birth weight infants: a Meta- analysis}

Sagad Omer Obeid Mohamed ${ }^{*}$, Sara Mohamed Ibrahim Ahmed, Reem Jamal Yousif Khidir, Mutaz Tarig Hassan Ahmed Shaheen, Mosab Hussen Mostafa Adam, Basil Abubakr Yagoub Ibrahim, Esra Osama Abdelrahman Elmahdi and Abubaker Shadoul Mohamed Farah

\begin{abstract}
Background: Neonatal admission hypothermia $(H T)$ is a frequently encountered problem in neonatal intensive care units (NICUs) and it has been linked to a higher risk of mortality and morbidity. However, there is a disparity in data in the existing literature regarding the prevalence and outcomes associated with $\mathrm{HT}$ in very low birth weight (VLBW) infants. This review aimed to provide further summary and analyses of the association between HT and adverse clinical outcomes in VLBW infants.

Methods: In July 2020, we conducted this review according to the Preferred Reporting Items for Systematic Reviews and Meta-Analyses guidelines. A systematic database search was conducted in MEDLINE (PubMed), Google Scholar, ScienceDirect, World Health Organization Virtual Health Library, Cochrane Library databases, and System for Information on Grey Literature in Europe (SIGLE). We included studies that assessed the prevalence of HT and/or the association between HT and any adverse outcomes in VLBW infants. We calculated the pooled prevalence and Odds Ratio (OR) estimates with the corresponding 95\% Confidence Interval (CI) using the Comprehensive metaanalysis software version 3.3 (Biostat, Engle-wood, NJ, USA; http://www.Meta-Analysis.com).

Results: Eighteen studies that fulfilled the eligibility criteria were meta-analyzed. The pooled prevalence of HT among VLBW infants was 48.3\% (95\% Cl, 42.0-54.7\%). HT in VLBW infants was significantly associated with mortality $(\mathrm{OR}=1.89 ; 1.72-2.09)$, intra-ventricular hemorrhage $(\mathrm{OR}=1.86 ; 1.09-3.14)$, bronchopulmonary dysplasia $(O R=1.28 ; 1.16-1.40)$, neonatal sepsis $(O R=1.47 ; 1.09-2.49)$, and retinopathy of prematurity $(O R=$ $1.45 ; 1.28-1.72)$.

Conclusion: Neonatal HT rate is high in VLBW infants and it is a risk factor for mortality and morbidity in VLBW infants. This review provides a comprehensive view of the prevalence and outcomes of HT in VLBW infants.
\end{abstract}

Keywords: Hypothermia, Very low birth weight, Meta-analysis

\footnotetext{
* Correspondence: s.oom123@yahoo.com

Faculty of Medicine, University of Khartoum, Alqasr Avenue, P.O. Box 102, Khartoum, Sudan
}

(c) The Author(s). 2021 Open Access This article is licensed under a Creative Commons Attribution 4.0 International License, which permits use, sharing, adaptation, distribution and reproduction in any medium or format, as long as you give appropriate credit to the original author(s) and the source, provide a link to the Creative Commons licence, and indicate if changes were made. The images or other third party material in this article are included in the article's Creative Commons licence, unless indicated otherwise in a credit line to the material. If material is not included in the article's Creative Commons licence and your intended use is not permitted by statutory regulation or exceeds the permitted use, you will need to obtain permission directly from the copyright holder. To view a copy of this licence, visit http://creativecommons.org/licenses/by/4.0/. The Creative Commons Public Domain Dedication waiver (http://creativecommons.org/publicdomain/zero/1.0/) applies to the data made available in this article, unless otherwise stated in a credit line to the data. 


\section{Background}

Neonatal deaths account for $40 \%$ of all under-five-years mortality and most of the deaths occur in developing countries $[1,2]$. In particular, low birth weight accounts for $60-80 \%$ of all neonatal deaths [2]. Causes of neonatal mortality include complications of prematurity, infections, birth asphyxia, congenital anomalies, and others $[3,4]$.

Several studies have reported an association between neonatal admission hypothermia (HT) and increased risk of mortality and morbidity in VLBW infants [5-13]. These outcomes associated with HT are particularly evident in VLBW newborns due to their impaired and easily overwhelmed temperature regulatory mechanism, which is mainly due to high surface area to mass ratio, decreased subcutaneous fat, lack of shivering response, and inadequate brown fat $[2,10-12]$. Laptook et al. found in an adjusted analysis that with each $1{ }^{\circ} \mathrm{C}$ decrease in body temperature of VLBW infants, sepsis and mortality risks increase by 11 and $28 \%$, respectively [13].

According to the World Health Organization (WHO), HT is defined as a core body temperature of less than $36.5^{\circ} \mathrm{C}$ and the severity is sub-classified into three grades: Cold stress or mild HT $\left(36.0-36.4{ }^{\circ} \mathrm{C}\right)$, moderate HT $\left(32.0-35.9^{\circ} \mathrm{C}\right.$ ), and severe HT (less than $32^{\circ} \mathrm{C}$ ) [14]. For each of these classifications, there are guidelines in place for responding to or managing HT [15]. Risk factors for HT include low gestational age, asphyxia, improper control of the thermal environment, inadequate breastfeeding, mode and place of delivery [16-19]. In addition, De Almeida et al. showed that maternal HT prior to delivery nearly doubles the chance that a newly born infant will have HT at five minutes after birth, indicating that maternal thermal care is an important measure for the prevention of neonatal HT [20].

Management of HT is considered a cornerstone for neonatal resuscitation as it reduces rates of neonatal mortality and morbidity [2, 21, 22]. According to the United Nations Children's Fund (UNICEF), these interventions can reduce the outcomes of HT by $18-42 \%$ [21]. These interventions that have been proposed to prevent HT in newborn infants include using a plastic cap, polyethylene bag wrapping, thermal mattress, controlling the room temperature, and active warming during cesarean delivery $[9,17,23,24]$. A quality improvement project on the implementation of thermoregulatory interventions showed a significant reduction of neonatal HT, which in turn improved neonatal outcomes [25].

There is disparity in reported data on the prevalence of HT in VLBW infants and the associated outcomes with HT despite the high burden of VLBW infant deliveries and HT [1, 11]. Therefore, we conducted this review to assess the burden and adverse clinical outcomes associated with HT among VLBW infants.

\section{Methods \\ Search strategy and inclusion criteria}

The methodology was developed from the Preferred Reporting Items for Systematic Reviews and MetaAnalyses (PRISMA) statement [26]. We performed a systematic literature search using the electronic databases of MEDLINE (PubMed), Google Scholar, ScienceDirect, WHO Virtual health library, Cochrane Library databases, and System for Information on Grey Literature in Europe (SIGLE) without limitations regarding sex, race, geographical area, or publication date. The search terms used were "low birth weight", "very low birth weight", "LBW", "VLBW", "hypothermia", and "low body temperature". Also, we reviewed the articles referenced by those identified articles in this search to ensure no possible relevant articles were missed.

The retrieved publications were imported into Rayyan software (QCRI, Doha, Qatar; http://rayyan.qcri.org) to expedite initial titles/abstracts screening and duplicates deletion [27]. The target population was the VLBW infants (those who were $<1500 \mathrm{~g}$ ) and the criteria for articles inclusion were cross-sectional, case-control, or cohort studies that assessed the prevalence of HT and/ or association between $\mathrm{HT}$ and any adverse outcome in VLBW infants. We excluded case reports, editorials, reviews, abstracts, non-English articles, and studies without sufficient data of interest. The titles and abstracts of all articles retrieved from this search were screened for potential inclusion in this review. Then, the full texts of studies deemed to be relevant were reviewed for inclusion according to the defined eligibility criteria.

\section{Quality assessment and data extraction}

Quality assessment of the included studies was done using the Joanna Briggs Institute critical appraisal checklists, which were set to assess the methodological quality of studies and to determine to what extent a study addressed the possibility of bias in study design, conduct, and data analysis [28]. Four independent reviewers extracted the relevant information using a designed data extraction form. Any disparity among the reviewers was resolved by discussion and consensus. For qualitative and quantitative data syntheses, we extracted the following information from each article and recorded them in a Microsoft Excel spreadsheet: authors, year of publication, study region, outcomes measured in the study, reference level used for definition of HT, number of VLBW infants, infants with HT, and infants with and without an adverse outcome in both hypothermic and nonhypothermic groups. 


\section{Statistical analysis}

The statistical analyses were carried out by using Comprehensive meta-analysis software version 3.3 (Biostat, Engle-wood, NJ, USA; http://www.Meta-Analysis.com). The heterogeneity was assessed through $\mathrm{I}^{2}$ test, which describes the percentage of variability in the effect estimates. If high heterogeneity was detected, we calculated the pooled summary prevalence and OR from the random-effects models. We conducted a metaregression analysis to determine the extent to which the continuous variables moderated the overall results. Publication bias was determined through Begg's test, Egger's test, and visual examination of the funnel plot $[29,30]$. If a publication bias was found, the Duvall and Tweedie's trim and fill method was used to add possible missing studies and to calculate the adjusted pooled value [31].

\section{Results}

\section{Studies characteristics and prevalence of HT among} VLBW infants

Our search retrieved records for 1840 published articles and the records screened after the removal of duplicates were 1438 articles. We excluded 1359 records in the title/abstracts screening phase after applying the exclusion criteria. Then, full texts of 79 studies were assessed for eligibility and quality. Lastly, a total of 18 studies conducted from 1981 to 2020 were included in the meta-analysis [5-7, 9-13, 20, 24, 32-39]. The studies selection process and the main findings are presented in (Fig. 1) and (Table. 1).
Among the 40,136 VLBW infants included in the analysis, the pooled prevalence of HT among VLBW infants was $48.3 \%$ (95\% CI, 42.0-54.7\%) (Fig. 2). No evidence of publication bias was detected based on examination of the funnel plot and from the results of Begg's test ( $p=$ $0.35)$ and Egger's test $(p=0.37)$ (Fig. 3). The metaregression showed that the prevalence of HT was not affected by the study year $(P=.721)$.

Risk of mortality among hypothermic VLBW infants

Eight studies had sufficient data to calculate the risk of death among hypothermic VLBW infants compared to the non-hypothermic VLBW population [5, 9-11, 20, 34, 37, 38]. The hypothermic VLBW infants have a higher risk of mortality with a pooled OR of 1.89 (95\% CI, 1.72-2.09) (Fig. 4) (Table. 2). Duvall and Tweedie's trim and fill method indicated three potential studies missing. However, the adjusted estimate was still significant and almost similar to the original findings after the virtual studies were appended, indicating that the result of this meta-analysis was steady $(\mathrm{OR}=1.86,95 \% \mathrm{CI}, 1.69-2.05)$.

\section{Risk of necrotizing enterocolitis (NEC) among hypothermic VLBW infants}

Four studies had sufficient data to calculate the risk of NEC among hypothermic VLBW infants compared to the non-hypothermic VLBW population [5, 9, 10, 37]. There was no significant difference between the two groups and the pooled OR was 1.04 (95\% CI, 0.89-1.21) (Fig. 4) (Table. 2). Duvall and Tweedie's trim and fill




Table 1 Descriptive summary of the studies included in the review

\begin{tabular}{|c|c|c|c|c|c|c|}
\hline Study & $\begin{array}{l}\text { Study } \\
\text { Year }\end{array}$ & Country & Adverse outcomes found to be associated with HT & $\begin{array}{l}\mathrm{HT} \text { cut } \\
\text { point }\left({ }^{\circ} \mathrm{C}\right)\end{array}$ & $\begin{array}{l}\text { No. of VLBW } \\
\text { infants }\end{array}$ & $\begin{array}{l}\text { No. (\%) of } \\
\text { infants with HT }\end{array}$ \\
\hline Levi et al. [38] & 1981 & USA & Mortality & 36.0 & 71 & $53(74.6 \%)$ \\
\hline $\begin{array}{l}\text { Neonatal Data } \\
\text { Collection Group [33] }\end{array}$ & 1993 & Malaysia & Mortality & 36.0 & 824 & $280(33.9 \%)$ \\
\hline $\begin{array}{l}\text { Malaysian VLBW group } \\
\text { [34] }\end{array}$ & 1997 & Malaysia & Mortality & 36.0 & 868 & $288(33.2 \%)$ \\
\hline Laptook et al. [13] & 2003 & USA & $\begin{array}{l}\text { Mortality ( } 28 \% \text { increase per } 1{ }^{\circ} \mathrm{C} \text { decrease) and sepsis } \\
\text { ( } 11 \% \text { increase per } 1{ }^{\circ} \mathrm{C} \text { decrease) }\end{array}$ & 36.0 & 5277 & $2475(46.9 \%)$ \\
\hline Sodemann et al. [39] & 2003 & $\begin{array}{l}\text { Guinea- } \\
\text { Bissau }\end{array}$ & Mortality & 34.5 & 23 & $13(56.5 \%)$ \\
\hline Demirel et al. [35] & 2006 & Turkey & $\mathrm{BPD}$ & 36.0 & 106 & $32(30.1 \%)$ \\
\hline Miller et al. [6] & 2007 & USA & Mortality, IVH, and sepsis & 36.5 & 8782 & $4953(56.4 \%)$ \\
\hline Ogunlesi et al. [32] & 2008 & Nigeria & Mortality & 36.5 & 15 & $14(93.3 \%)$ \\
\hline Ting et al. [7] & 2011 & Canada & $\begin{array}{l}\text { Mortality, sepsis and adverse neurodevelopmental } \\
\text { outcomes }\end{array}$ & 36.5 & 2739 & $968(35.3 \%)$ \\
\hline Audeh et al. [24] & 2011 & Israel & Non & 35.5 & 271 & $100(36.9 \%)$ \\
\hline Lyu et al. [37] & 2012 & Canada & $\begin{array}{l}\text { Mortality, severe neurological injury, severe ROP, NEC, } \\
\text { and BPD }\end{array}$ & 36.5 & 9833 & $3516(35.7 \%)$ \\
\hline De Almeida et al. [20] & 2012 & Brazil & Mortality & 36.0 & 1764 & $900(51.0 \%)$ \\
\hline Guinsburg et al. [12] & 2015 & Brazil & $\begin{array}{l}\text { Unfavorable outcome (in-hospital mortality or survival } \\
\text { with BPD, IVH III/IV, PVL and/or ROP) }\end{array}$ & 36.0 & 2646 & $868(32.8 \%)$ \\
\hline Chang et al. [10] & 2015 & Taiwan & Mortality and RDS & 36.5 & 341 & $262(76.8 \%)$ \\
\hline Das et al. [36] & 2016 & USA & Sepsis & 36.0 & 174 & $16(9.19 \%)$ \\
\hline Caldas et al. [9] & 2019 & Brazil & Mortality and NEC & 36.5 & 4356 & $2339(53.7 \%)$ \\
\hline Ng'eny et al. [11] & 2019 & $\begin{array}{l}\text { South } \\
\text { Africa }\end{array}$ & Mortality and metabolic acidosis & 36.0 & 799 & $453(56.7 \%)$ \\
\hline Yu et al. [5] & 2020 & China & Mortality, RDS, IVH, NEC, and sepsis & 36.5 & 1247 & $1100(88.2 \%)$ \\
\hline
\end{tabular}

\begin{tabular}{|c|c|c|c|c|c|c|c|c|c|c|}
\hline \multirow[t]{2}{*}{$\underline{\text { Study name }}$} & \multirow[b]{2}{*}{$\begin{array}{c}\text { Event } \\
\text { rate }\end{array}$} & \multicolumn{3}{|c|}{ Statistics for each study } & \multirow[b]{2}{*}{ p-Value } & \multicolumn{4}{|c|}{ Event rate and $95 \% \mathrm{Cl}$} & \\
\hline & & $\begin{array}{c}\text { Lower } \\
\text { limit }\end{array}$ & $\begin{array}{l}\text { Upper } \\
\text { limit }\end{array}$ & Z-Value & & & & & & \\
\hline Levi et al [38] & 0.746 & 0.633 & 0.834 & 3.959 & 0.000 & & & & & $y$ \\
\hline Neonatal Data Collection Group [33] & 0.340 & 0.308 & 0.373 & -9.030 & 0.000 & & & & & \\
\hline Malaysian VLBW group [34] & 0.332 & 0.301 & 0.364 & -9.712 & 0.000 & & & & & \\
\hline Laptook et al [13] & 0.469 & 0.456 & 0.483 & -4.499 & 0.000 & & & & & \\
\hline Sodemann et al [39] & 0.565 & 0.363 & 0.748 & 0.624 & 0.533 & & & & & \\
\hline Demirel et al [35] & 0.302 & 0.222 & 0.396 & -3.962 & 0.000 & & & & & \\
\hline Miller et al [6] & 0.564 & 0.554 & 0.574 & 11.961 & 0.000 & & & & & \\
\hline Ogunlesi et al [32] & 0.933 & 0.648 & 0.991 & 2.550 & 0.011 & & & & & \\
\hline Ting et al [7] & 0.353 & 0.336 & 0.372 & -15.113 & 0.000 & & & & & \\
\hline Audeh et al [24] & 0.369 & 0.314 & 0.428 & -4.262 & 0.000 & & & & & \\
\hline Lyu et al [37] & 0.358 & 0.348 & 0.367 & -27.84 & 0.000 & & & & & \\
\hline De Almeida et al [20] & 0.510 & 0.487 & 0.533 & 0.857 & 0.391 & & & & & \\
\hline Guinsburg et al [12] & 0.328 & 0.310 & 0.346 & -17.317 & 0.000 & & & & & \\
\hline Chang et al [10] & 0.768 & 0.721 & 0.810 & 9.340 & 0.000 & & & & & \\
\hline Das et al [36] & 0.092 & 0.057 & 0.145 & -8.729 & 0.000 & & & & & \\
\hline Caldas et al [9] & 0.537 & 0.522 & 0.552 & 4.874 & 0.000 & & & & & \\
\hline Ng'eny et al [11] & 0.567 & 0.532 & 0.601 & 3.774 & 0.000 & & & & & \\
\hline \multirow[t]{3}{*}{ Yu et al [5] } & 0.882 & 0.863 & 0.899 & 22.919 & 0.000 & & & & & \\
\hline & 0.483 & 0.420 & 0.547 & -0.510 & 0.610 & & & & & \\
\hline & & & & & & -0.50 & -0.25 & 0.00 & 0.25 & 0.50 \\
\hline
\end{tabular}




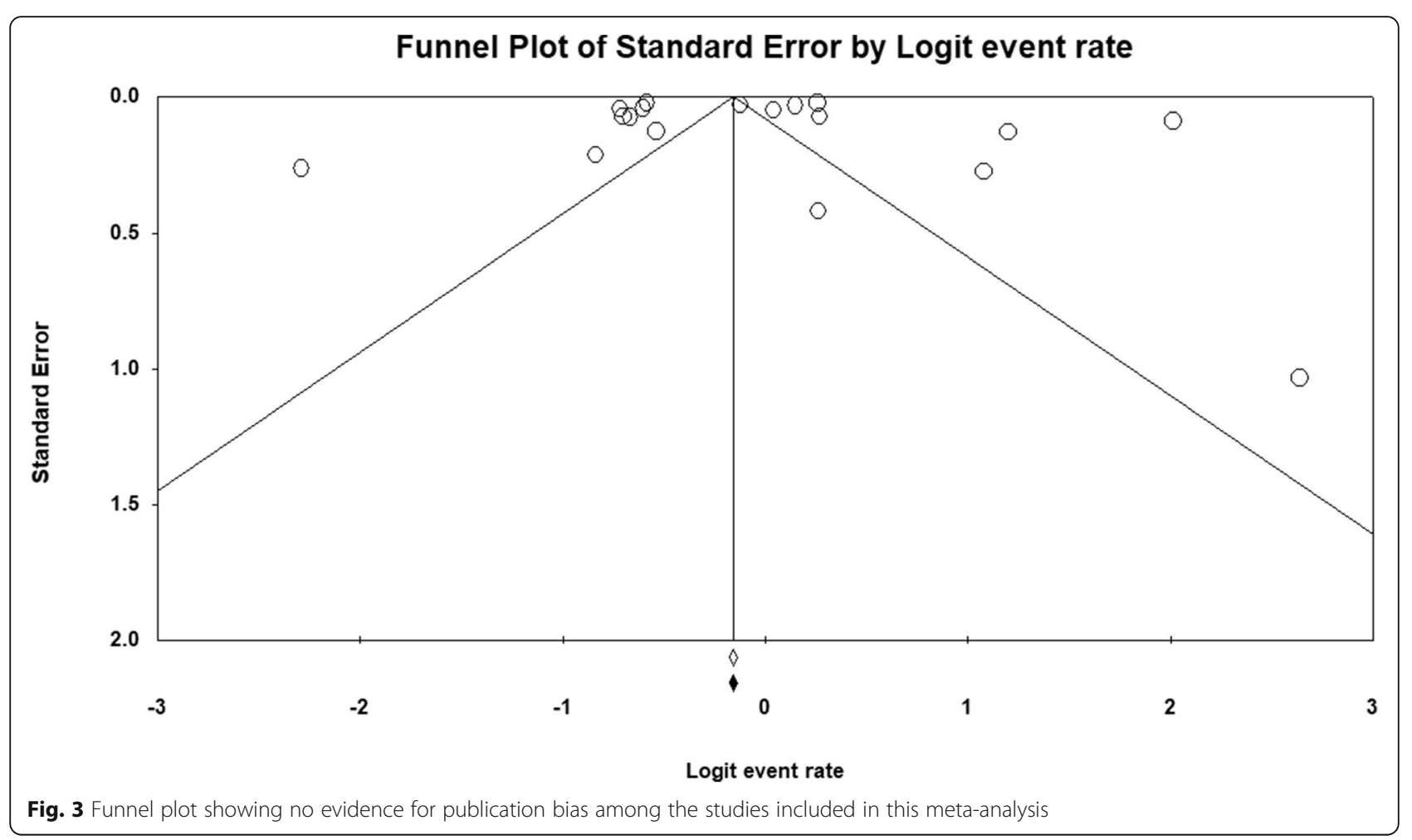

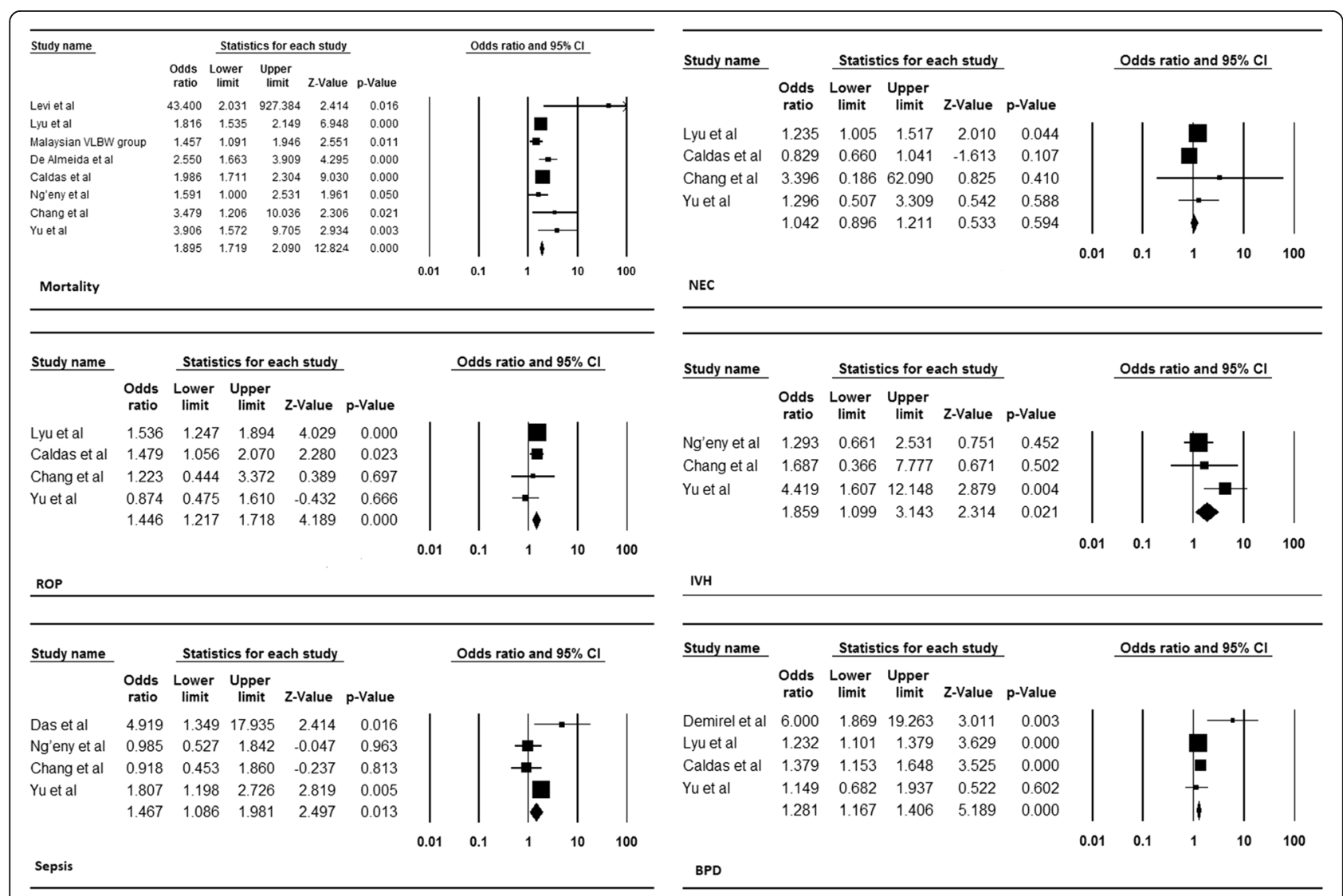

Fig. 4 Pooled OR of Mortality NEC, IVH, BPD, Sepsis, and ROP among hypothermic VLBW infants 
Table 2 Meta-analyses of the adverse outcomes associated with HT in VLBW infants

\begin{tabular}{llll}
\hline Adverse outcome & No. of studies & Pooled OR (95\% Cl) & $p$ value for OR \\
\hline Death & $\mathbf{8}$ & $1.89(95 \% \mathrm{Cl}, 1.72-2.09)$ & $P<.001$ \\
NEC & $\mathbf{4}$ & $1.04(95 \% \mathrm{Cl}, 0.89-1.21)$ & $P=.594$ \\
IVH & $\mathbf{3}$ & $1.86(95 \% \mathrm{Cl}, 1.09-3.14)$ & $P=.021$ \\
BPD & $\mathbf{4}$ & $1.28(95 \% \mathrm{Cl}, 1.16-1.40)$ & $P<.001$ \\
Sepsis & $\mathbf{4}$ & $1.45(95 \% \mathrm{Cl}, 1.22-1.49)$ & $P<.001$ \\
ROP & $\mathbf{4}$ & $1.46(95 \% \mathrm{Cl}, 1.08-1.98)$ & $P=.013$ \\
\hline
\end{tabular}

method indicated one potential study missing. However, the adjusted estimate was still insignificant and almost similar to the original findings after the virtual study was appended, indicating that the result of this meta-analysis was steady $(\mathrm{OR}=1.03,95 \% \mathrm{CI}, 0.76-1.42)$.

\section{Risk of intra-ventricular hemorrhage (IVH) among} hypothermic VLBW infants

Three studies had sufficient data to calculate the risk of developing IVH among hypothermic VLBW infants compared to the non-hypothermic VLBW population [5, 10, 11]. The hypothermic VLBW infants have a higher risk of IVH with a pooled OR of 1.86 (95\% CI, 1.093.14) (Fig. 4) (Table. 2).

\section{Risk of bronchopulmonary dysplasia (BPD) among hypothermic VLBW infants}

Four studies with sufficient data to calculate the risk of BPD among hypothermic VLBW infants compared to the non-hypothermic VLBW population [5, 9, 35, 37]. The hypothermic VLBW infants have a higher risk of BPD with a pooled OR of 1.28 (95\% CI, 1.16-1.40) (Fig. 4) (Table. 2). Duvall and Tweedie's trim and fill method indicated one potential study missing and the adjusted estimate was $(\mathrm{OR}=1.26,95 \% \mathrm{CI}, 0.95-1.69)$.

Risk of neonatal sepsis among hypothermic VLBW infants Four studies with sufficient data to calculate the risk of neonatal sepsis among hypothermic VLBW infants compared to the non-hypothermic VLBW population $[5,9$, 10, 37]. The hypothermic VLBW infants have a higher risk of sepsis with a pooled OR of 1.47 (95\% CI, 1.092.49) (Fig. 4) (Table. 2).

\section{Risk of retinopathy of prematurity (ROP) among hypothermic VLBW infants}

Four studies with sufficient data to calculate the risk of ROP among hypothermic VLBW infants compared to the non-hypothermic VLBW population $[5,10,11,36]$. The hypothermic VLBW infants have a higher risk of ROP with a pooled OR of 1.45 (95\% CI, 1.28-1.72) (Fig. 4) (Table. 2).

\section{Discussion}

In this review, we provided a comprehensive view of the prevalence of HT and its associated outcomes in VLBW infants. The prevalence of HT among VLBW infants was high and our result is close to a 2020-systematic review which reported that the prevalence of neonatal HT in East African countries was 57.2\% [40]. Most of the studies included in our meta-analysis defined HT as axillary body temperature below $36.0^{\circ} \mathrm{C}$ or $36.5^{\circ} \mathrm{C}$. There were two studies that used different cut-off points for the definition of HT; Audeh et al. found that $36.9 \%$ of the 271 VLBW infants in three Israeli centers had body temperature below $35.5^{\circ} \mathrm{C}$ and Sodemann et al. in a cohort study conducted in Guinea-Bissau found that body temperature below $34.5^{\circ} \mathrm{C}$ significantly increased the risk of death by approximately five times in the first 7 days of life [24, 39].

The adjusted multivariate analyses in the reviewed studies showed that HT was linked to increased risk of one or more adverse outcomes in VLBW infants, indicating that these findings were more than mere associations in the context of prematurity. Furthermore, Yu et al. showed that the correlation between HT and mortality was quadratic function equation and Lye et al. showed that the relationship between body temperature and adverse neonatal outcomes was U-shaped, in which the lowest rates of adverse outcomes were associated with the normal temperatures [5, 37].

These findings are explainable from the perspective of the pathophysiology of HT. Few studies provided potential explanations for the pathophysiological mechanisms by which neonatal HT lead to consequent mortality and adverse clinical outcomes [41]. It has been reported that HT affects virtually all systems causing wasting of the body's stores of carbohydrate, protein, and fat due to the effect of the stress hormones such as cortisol and catecholamines, transient increased heart rate followed by bradycardia and serious electrocardiographic changes, decreased blood flow to the vital organs secondary to HT-mediated decrease in cardiac output, increased blood viscosity, and unpredictable fluctuations in serum electrolytes [41]. It has been shown that with prolongation of HT, the body's oxygen consumption declines at a rate of $6 \%$ with each degree fall in body temperature 
with an inverse relationship between heat lost and serum glucose level [41].

The current review further confirmed the association of HT with VLBW neonatal deaths. The risk of mortality among hypothermic infants was reported as being highest within the first 7 days of life [11]. HT increased death rates by $39.5,42$, and $64 \%$ according to the findings of Guinsburg et al., Ting et al., and De Almeida et al., respectively $[7,12,20]$. Ogunlesi et al. showed that the case fatality rate (CFR) was significantly higher for hypothermic babies, especially in babies who weighed < $1 \mathrm{~kg}$ [32]. It is noteworthy that the incidence of mortality varied with varying degrees of HT [6]. A recent review showed that HT-associated mortality is related to the quality of neonatal care and it could be used as a quality indicator [42]. Simiyu et al. found that the mortality rate among low birth weight infants with HT was 84\% [43]. In addition, a comparison of admission temperature between survivors and non-survivors showed a significant difference where the average body temperature was $35.4^{\circ} \mathrm{C}$ and $34.8^{\circ} \mathrm{C}$ respectively [44].

However, it is worth noting that attributing the poor neonatal outcome to HT might in some cases be tricky. In three groups of VLBW infants (750-999, 1000-1249, and $1250-1500 \mathrm{~g}$ ) for instance as noted by Joelle et al., despite the significantly higher incidence of HT in the smallest infants compared to the (1250-1500 g) infants, HT was only significantly more common in the subgroup of infants who died in the larger groups, but not in the smallest infants group [45].

Our analysis concluded that there was an association between HT and IVH. Miller et al. found the association was with moderate HT specifically, whilst Yu et al. found the association with all types of HT [5, 6]. Guinsberg et al. found in their study that the IVH acquired by neonates due to HT was specifically of the IVH grade $3-4$ [12].

Studies regarding NEC were controversial, and we did not detect an association between neonatal HT and NEC. Guinsburg et al. reported that NEC contributed synergistically to the development of unfavorable outcomes along with HT [12]. Caldas et al. described the significant protective association between admission HT and NEC like previous reports which showed that mild induced therapeutic HT may have some protective effect as rescue therapy for NEC in preterm infants [9].

Neonatal sepsis being linked to HT could be attributed to facts reported in the adult population undergoing surgery, where peri-operative HT was found to propagate post-operative infectious complications through temperature-mediated impaired immune function [13]. In a quality improvement project, the risk of nosocomial sepsis was significantly lowered in the period after the intervention to reduce neonatal HT [25]. However, a number of confounding factors have been established to contribute to the development of sepsis including the length of hospital stay and level of prematurity of the infant [36].

A limitation to be considered in this review is the paucity of publications on the associated outcomes with HT, which would be useful to reflect since several countries reported a high prevalence of neonatal HT, nonetheless still neglect the lack of thermal protection needed for newborn survival $[2,40,41]$. In such a situation, the magnitude of the burden would help emphasize the importance of interventional measures to be taken. Another limitation is the inclusion of studies published only in English, which could compromise representativeness. Lastly, data on the risk of several adverse outcomes were obtainable from few studies. There is a need for large prospective studies with appropriate controls to elaborate more on these issues.

\section{Conclusions}

Neonatal HT rate is high in VLBW infants and it is a vital risk factor for mortality and morbidity among them. Healthcare providers need to be aware of the clinically important association between HT and adverse clinical outcomes to ensure effective management.

\section{Abbreviations \\ VLBW: Very Low birth weight: HT: Hypothermia; NEC: Necrotizing enterocolitis; IVH: Intra-ventricular hemorrhage; ROP: Retinopathy of prematurity; BPD: Bronchopulmonary dysplasia; CFR: Case fatality rate}

\section{Acknowledgments}

Dr. Abeer Mohamed is greatly acknowledged for her help in proofreading the manuscript.

\section{Authors' contributions}

(SM) undertook research design and analysis; (SA, RK, MS, and MA) participated in searching databases; (SM, BI, EE, and AF) undertook articles screening and data extraction. All authors interpreted the results and drafted the manuscript. All authors revised and approved the final manuscript.

\section{Funding}

No fund.

Availability of data and materials

The datasets used during the current study are available from the corresponding author on reasonable request.

\section{Declarations}

Ethics approval and consent to participate Not applicable.

Consent for publication

Not applicable.

Competing interests

The authors declare that they have no competing interests. 
Received: 10 January 2021 Accepted: 6 September 2021 Published online: 15 September 2021

\section{References}

1. Amadi HO, Olateju EK, Alabi P, Kawuwa MB, Ibadin MO, Osibogun AO. Neonatal hyperthermia and thermal stress in low-and middle-income countries: a hidden cause of death in extremely low-birthweight neonates. Paediatr Int Child Health. 2015;35(3):273-81. https://doi.org/10.1179/204 6905515Y.0000000030.

2. Lunze K, Bloom DE, Jamison DT, Hamer DH. The global burden of neonatal hypothermia: systematic review of a major challenge for newborn survival. BMC Med. 2013;11(1). https://doi.org/10.1186/1741-7015-11-24.

3. Black RE, Cousens S, Johnson HL, Lawn JE, Rudan I, Bassani DG, et al. Global, regional, and national causes of child mortality in 2008: a systematic analysis. Lancet. 2010;375(9730):1969-87. https://doi.org/10.1016/S0140-673 6(10)60549-1.

4. Bang AT, Reddy HM, Bang RA, Deshmukh MD. Why do neonates die in rural Gadchiroli, India? (Part II): Estimating population attributable risks and contribution of multiple morbidities for identifying a strategy to prevent deaths. J Perinatol. 2005;25 Suppl 1:S35-43. https://doi.org/10.1038/sj.jp. 7211270.

5. $\quad Y u$ YH, Wang L, Huang L, Wang LL, Huang XY, Fan XF, et al. Association between admission hypothermia and outcomes in very low birth weight infants in China: a multicentre prospective study. BMC Pediatr. 2020;20:321. https://doi.org/10.11 86/s12887-020-02221-7.

6. Miller SS, Lee HC, Gould JB. Hypothermia in very low birth weight infants: Distribution, risk factors and outcomes. J Perinatol. 2011;31 Suppl 1:S49-56. https://doi.org/10.1038/jp.2010.177.

7. Ting JY, Synnes AR, Lee SK, Shah PS. Association of admission temperature and death or adverse neurodevelopmental outcomes in extremely lowgestational age neonates. J Perinatol. 2018;38(7):844-9. https://doi.org/10.1 038/s41372-018-0099-6.

8. Feldman A, de Benedictis B, Alpan G, la Gamma EF, Kase J. Morbidity and mortality associated with rewarming hypothermic very low birth weight infants. J NeonatalPerinatal Med. 2016;9(3):295-302. https:/doi.org/10.3233/NPM-16915143.

9. Caldas DSJP, Ferri WAG, Marba STM, Aragon DC, Guinsburg R, de Almeida MFB, et al. Admission hypothermia, neonatal morbidity, and mortality: evaluation of a multicenter cohort of very low birth weight preterm infants according to relative performance of the center. Eur J Pediatr. 2019;178(7): 1023-32. https://doi.org/10.1007/s00431-019-03386-9.

10. Chang HY, Sung YH, Wang SM, Lung HL, Chang JH, Hsu CH, et al. Shortand long-term outcomes in very low birth weight infants with admission hypothermia. PLoS One. 2015;10(7):e0131976. https://doi.org/10.1371/journa I.pone.0131976.

11. Ng'eny JC, Velaphi S. Hypothermia among neonates admitted to the neonatal unit at a tertiary hospital in South Africa. J Perinatol. 2020;40(3): 433-8. https://doi.org/10.1038/s41372-019-0539-y.

12. Guinsburg R, de Almeida MFB, de Castro JS, Silveira RC, Caldas JPDS, Fiori $\mathrm{HH}$, et al. Death or survival with major morbidity in VLBW infants born at Brazilian neonatal research network centers. J Matern Fetal Neonatal Med. 2016;29(6):1005-9. https://doi.org/10.3109/14767058.2015.1031740.

13. Laptook AR, Salhab W, Bhaskar B. Admission temperature of low birth weight infants: Predictors and associated morbidities. Pediatrics. 2007;119(3): e643-9. https://doi.org/10.1542/peds.2006-0943.

14. World Health Organization. Thermal protection of the newborn : a practical guide. Book [Internet]; 1997. p. 68. Available from: https://apps.who.int/iris/ bitstream/handle/10665/63986/WHO_RHT_MSM_97.2.pdf;jsessionid=4D411 EC9439429CC27C36A844A1B811E?sequence=1

15. Mullany LC. Neonatal Hypothermia in Low-Resource Settings. Semin Perinatol. 2010;34:426-33.

16. Vohra S, Frent G, Campbell V, Abbott M, Whyte R. Effect of polyethylene occlusive skin wrapping on heat loss in very low birth weight infants at delivery: a randomized trial. J Pediatr. 1999;134(5):547-51. https://doi.org/1 0.1016/S0022-3476(99)70238-6.

17. Hsu KH, Chiang MC, Lin SW, Lin JJ, Wang YC, Lien R. Thermal blanket to improve thermoregulation in preterm infants: a randomized controlled trial. Pediatr Crit Care Med. 2015;16(7):637-43. https://doi.org/10.1097/PCC. 0000000000000447.

18. Mullany LC, Katz J, Khatry SK, Leclerq SC, Darmstadt GL, Tielsch JM. Neonatal hypothermia and associated risk factors among newborns of southern
Nepal [Internet]. BMC Med. 2010;8 Available from: http://www.biomedcentra com/1741-7015/8/43.

19. Urubuto F, Agaba F, Choi J, Dusabimana R, Teteli R, Kumwami M, Conard C, O'Callahan C, Cartledge P. Prevalence, risk factors and outcomes of neonatal hypothermia at admission at a tertiary neonatal unit, Kigali, Rwanda - a cross-sectional study. J Matern Fetal Neonatal Med. 2021;34(17):2793-800. https://doi.org/10.1080/14767058.2019.1671334.

20. de Almeida MF, Guinsburg R, Sancho GA, Rosa IR, Lamy ZC, Martinez FE, et al. Brazilian Network on Neonatal Research. Hypothermia and early neonatal mortality in preterm infants. J Pediatr. 2014;164(2):271-5.e1. https://doi.org/10.1016/j.jpeds.2013.09.049.

21. Abd-El Hamid SA, Badr-El Din MM, Dabous NI, Saad KM. Effect of the use of a polyethylene wrap on the morbidity and mortality of very low birth weight infants in Alexandria university children's hospital. J Egypt Public Health Assoc. 2012:87(5-6):104-8. https://doi.org/10.1097/01.EPX.0000421565.24496.d9.

22. Perlman JM, Wyllie J, Kattwinkel J, Atkins DL, Chameides L, Goldsmith JP, Guinsburg R, Hazinski MF, Morley C, Richmond S, Simon WM, Singhal N, Szyld E, Tamura M, Velaphi S, Neonatal Resuscitation Chapter Collaborators. Part 11: neonatal resuscitation: 2010 international consensus on cardiopulmonary resuscitation and emergency cardiovascular care science with treatment recommendations. Circulation. 2010;122(16 Suppl 2):S51638. https://doi.org/10.1161/CIRCULATIONAHA.110.971127.

23. Laptook AR, Bell EF, Shankaran S, Boghossian NS, Wyckoff MH, Kandefer $\mathrm{S}$, et al. Admission Temperature and Associated Mortality and Morbidity among Moderately and Extremely Preterm Infants. J Pediatr. 2018;192: 53-59.e2.

24. Audeh S, Smolkin T, Bental Y, Haramati Z, Blazer S, Litig E, et al. Does admission hypothermia predispose to intraventricular hemorrhage in verylow-birth-weight infants? Neonatology. 2011;100(4):373-9. https://doi.org/1 $0.1159 / 000327370$

25. Sharma D, Murki S, Kulkarni D, Pawale D, Vardhelli V, Anne RP, et al. The impact of a quality improvement project to reduce admission hypothermia on mortality and morbidity in very low birth weight infants. Eur J Pediatr. 2020;179(12):1851-8. https://doi.org/10.1007/s00431-020-03711-7.

26. Liberati A, Altman DG, Tetzlaf J, Mulrow C, Gotzsche PC, loannidis JP, et al. The PRISMA statement for reporting systematic reviews and meta-analyses of studies that evaluate health care interventions: explanation and elaboration. J Clin Epidemiol. 2009;62(10):e1-34. https://doi.org/10.1016/j. jclinepi.2009.06.006.

27. Ouzzani M, Hammady H, Fedorowicz Z, Elmagarmid A. Rayyan - a web and mobile app for systematic reviews. Syst Rev. 2016;5:210. https://doi. org/10.1186/s13643-016-0384-4.

28. The Joanna Briggs Institute. Joanna Briggs Institute Reviewer's Manual 2018 [Available from: https://wiki.joannabriggs.org/display/MANUAL/Joanna+ Briggs+Institute+Reviewer\%27s+Manual

29. Borenstein M, Hedges LV, Higgins J, Rothstein HR. A basic introduction to fixed-effect and random-effects models for meta-analysis. Res Synth Methods. 2010;1(2):97-111. https://doi.org/10.1002/jrsm.12.

30. Begg CB, Mazumdar M. Operating characteristics of a rank correlation test for publication bias. Biometrics. 1994;1:1088-101.

31. Duval S, Tweedie R. Trim and fl: a simple funnel-plot-based method of testing and adjusting for publication bias in meta-analysis. Biometrics. 2000; 56(2):455-63. https://doi.org/10.1111/j.0006-341X.2000.00455.x.

32. Ogunles TA, Ogunfowora OB, Adekanmbi FA, Fetuga BM, Olanrewaju DM. Point-of-admission hypothermia among high-risk Nigerian newborns. BMC Pediatr. 2008;8(1):40. https://doi.org/10.1186/1471-2431-8-40.

33. Neonatal Data Collection Group. Outcome of Inborn Compared with Outborn Very Low Birth Weight Infants Admitted to Level 3 Malaysian Nurseries. Med J Malaysia. 1995;50:1.

34. Malaysian very low birth weight study group. A national study of risk factors associated with mortality in very low birthweight infants in the Malaysian neonatal intensive care units. J Faediatr Child Health. 1997;33(1):18-25. https://doi.org/10.1111/j.1440-1754.1997.tb00985.x.

35. Demirel N, Bas AY, Zenciroglu A. Bronchopulmonary Dysplasia in Very Low Birth Weight Infants, Indian J Pediatr. 2009;76. https://doi.org/10.1007/s12098\%2D\%2 D009\%2D\%2D0110-5.

36. Das A, Shukla S, Rahman N, Gunzler D, Aughali N. Clinical Indicators of Late Onset Sepsis Workup in very Low -Birth-Weight Infants in the Neonatal Intensive Care Unit. Am J Perinatol. 2016. https://doi.org/10.1055/s-0036-1579648.

37. Lyu Y, Shah PS, Ye XY, Warre R, Piedboeuf B, Deshpandey A, et al. Association between admission temperature and mortality and major morbidity in 
preterm infants born at fewer than 33 weeks' gestation. JAMA Pediatr. 2015; 169(4):e150277. https://doi.org/10.1001/jamapediatrics.2015.0277.

38. Levi S, Taylor W. RN, Robinson LE, levy LI. Analysis of morbidity and outcomes of infants weighing less than 800 grams at birth. South Med J. 1984;77(8):8-986. https://doi.org/10.1111/j.1365-3156.2008.02113.x.

39. Sodemann M, Nielsen J, Veirum J, Jakobsen MS, Biai S, Aaby P. Hypothermia of newborns is associated with excess mortality in the first 2 months of life in Guinea-Bissau, West Africa. 2008;13(8):980-6. https://doi.org/10.1111/j.13 65-3156.2008.02113.x.

40. Beletew B, Mengesha A, Wudu M, Abate M. Prevalence of neonatal hypothermia and its associated factors in East Africa: a systematic review and meta-analysis. BMC Pediatr. 2020;20(1):148. https://doi.org/10.1186/s12 887-020-02024-w.

41. Onalo R. Neonatal hypothermia in sub-Saharan Africa: a review. Niger I Clin Pract. 2013;16(2):129-38. https://doi.org/10.4103/1119-3077.110120.

42. Trevisanuto $D$, Testoni $D$, de Almeida MFB. Maintaining normothermia: why and how? Semin Fetal Neonatal Med. 2018;23(5):333-9. https://doi.org/10.1 016/j.siny.2018.03.009.

43. Simiyu DE. Morbidity and mortality of low birth weight infants in the new born unit of Kenyatta national hospital, Nairobi. East Afr Med J. 2004;81(7): 367-74. https://doi.org/10.4314/eamj.v81i7.9193.

44. Yu VY, Downe L, Astbury J, et al. Perinatal factors and adverse outcome in extremely low birthweight infants. Arch Dis Child. 1986;61:554-8. https://doi. org/10.1136/adc.61.6.554.

45. Jolly H, Molyneux P, Newell DJ. A controlled study of the effect on premature babies of temperature. J Pediatr. 1962;60(6):889-94. https://doi. org/10.1016/50022-3476(62)80174-7.

\section{Publisher's Note}

Springer Nature remains neutral with regard to jurisdictional claims in published maps and institutional affiliations.

Ready to submit your research? Choose BMC and benefit from:

- fast, convenient online submission

- thorough peer review by experienced researchers in your field

- rapid publication on acceptance

- support for research data, including large and complex data types

- gold Open Access which fosters wider collaboration and increased citations

- maximum visibility for your research: over $100 \mathrm{M}$ website views per year

At BMC, research is always in progress.

Learn more biomedcentral.com/submissions 